\title{
MAKNA DAN PENGHARGAAN PEREMPUAN NUAULU DALAM INISIASI RITUAL PINAMOU DI PULAU SERAM
}

\author{
Telfrin Lasamahu $\left({ }^{1}{ }^{*}\right)$, Izak Y. M. Lattu $\left({ }^{2}\right)$, Rama Tulus Pilakoanu $\left({ }^{3}\right)$ \\ ${ }^{123}$ Graduate School of Universitas Kristen Satya Wacana, Jawa Tengah, Indonesia.
}

\begin{tabular}{ll} 
ARTICLE INFORMATION \\
\hline Submitted & $: 16^{\text {th }}$ September, 2019 \\
Review & $: 01^{\text {st }}$ February, 2020 \\
Accepted & $: 03^{\text {rd }}$ May, 2020 \\
Published & $: 1^{\text {st }}$ June 2020 \\
Available Online & $:$ June 2020 \\
KEYWORDS
\end{tabular}

Women's award; Initiation; Pinamou; Nuaulu; Seram Island

CORRESPONDENCE

*E-mail: lasamahutelfrin@gmail.com

\begin{abstract}
A B S T R A C T
This article aims to analyze the appreciation of women in the Pinamou ritual as an initiation ritual for women. The method used is a qualitative research method, with data acquisition through observation, interviews, audio-visual material, and literature studies. The study found in Pinamou ritual has an appreciation for the women who see in mythology about women. Then, it shows the figure of women as the successors of the life of a community and also as a source of blessing for both personal and community living in the community. The Pinamou ritual also has an affirmation of the initiation ritual that must carry out to reach the customary order in the community and become a place to look back at every meaning in the ritual performed.
\end{abstract}

\section{A. PENDAHULUAN}

$\mathrm{K}$ ebudayaan patriakhi yang mendominasi struktur masyarakat dan menjadikan pandangan dalam masyarakat yang menandai perempuan sebagai sosok yang lemah menjadi suatu dilema yang berkepanjangan. Konstruksi pemikiran yang telah mengakar ini bahkan tidak disadari merupakan adopsi dari kebudayaan luar yang dibawa masuk dan mengalami penjajahan secara fisik bahkan juga penjajahan dalam konteks budaya yang sering dianggap berada dalam penguasaan laki-laki yang mengandung unsur patriakal dalam suatu komunitas masyarakat. Pengaruh kebudayaan yang berkembang cenderung melihat akan ketimpangan bagi perempuan dalam masyarakat. Dengan kebudayaan dalam ritual yang dijalankan bagi perempuan memuat penghargaan bagi perempuan itu sendiri dalam suatu komunitas masyarakat. Ritual Pinamou yang merupakan warisan lokal kebudayaan yang ada dalam masyarakat Nuaulu di Pulau Seram, hendak mengemukakan tentang penghargaan terhadap perempuan yang ada dan terkandung dalam ritual yang menjadi warisan lokal dari masyarakat setempat. Ritual Pinamou merupakan Ritual masa akhil balik dari seorang perempuan dari masa kanak-kanak menuju masa dewasa dengan mendapat menstruasi pertama. Terdapat tahapan dalam ritual Pinamou ini, yang dimulai dengan anak perempuan masuk dalam rumah khusus yang disebut Posune ${ }^{1}$ dan kemudian puncaknya dengan pemberian minyak bagi seluruh laki-laki dalam masyarakat sebagai berkat dalam pencarian nafkah. Perempuan yang dipandang dalam strata dan dianggap rendah mempunyai andil besar dalam suatu komunitas masyarakat. Perempuan menjadi sumber berkat bagi kehidupan keluarga dan masyarakat. Ritual yang dijalankan juga memperlihatkan bahwa kebudayaan yang dilakukan dapat di lihat sebagai jawaban dari pemikiran konstruksi dunia barat yang masih saja mencari bagaimana peran perempuan dan apa yang harus dihargai dari perempuan. Nilai dari seorang perempuan dapat 
dilihat dalam pelaksanaan ritual dalam suatu komunitas. Ritual yang dilakukan menjadi suatu sistem dalam kehidupan masyarakat setempat yang dijunjung tinggi untuk memperlihatkan penghargaan bagi perempuan dalam ritual yang dilakukan.

Penelitian dalam Suku Nuaulu juga telah dilakukan oleh banyak ahli dalam sosial keagamaan $^{2}$, namun para peneliti tersebut tidak memberikan perhatian pada tempat perempuan dalam ritual masyarakat Nuaulu dalam konteks ritual inisiasi pada perempuan (Pinamou). Dalam konteks budaya lokal tersimpan penghargaan yang tinggi terhadap seorang perempuan. Terdapat beberapa penulisan tentang perempuan yakni salah satunya dalam masyarakat Nuaulu, yakni Makna Menstruasi Bagi Perempuan Suku Naulu-Dusun Rohua Kabupaten Maluku Tengah Provinsi Maluku ${ }^{3}$. Setelah menelaah tulisan ini, penulis tidak menemukan penghargaan terhadap perempuan Nuaulu dalam ritual Pinamou sebagai ritual inisiasi. Perbedaan tulisan tersebut dengan peneliti adalah ingin melihat penghargaan terhadap perempuan dalam ritual Pinamou sebagai ritual inisiasi pada masyarakat Nuaulu di Pulau Seram.

Ritual Pinamou dalam konteks Nuaulu bukan hanya sebatas ritual inisiasi yang pada dasarnya harus dilakukan. Namun dalam penggalian makna dalam ritual ini adalah penghargaan terhadap perempuan nuaulu dalam ritual Pinamou. Pemaknaan lebih dalam akan terlihat dalam kearifan lokal yang dibangun dalam suatu penghargaan dalam ritual yang dilakukan. Ritual yang dilakukan sebagai bentuk penghargaan bagi seorang perempuan sebagai penerus komunitas dalam masyarakat, menjadi bagian penting yang tak dapat dipungkiri dalam keberadaan perempuan dalam ritual yang dilakukan dalam suatu komunitas. Artikel ini bertujuan menganalisis penghargaan terhadap perempuan Nuaulu dalam Ritual Inisiasi di Pulau Seram yang berfokus pada ritual Pinamou. Di samping itu, juga bertujuan untuk menjelaskan adanya makna penghargaan terhadap perempuan yang terkandung dalam ritual Pinamou yang menjadi warisan lokal dari masyarakat setempat.

\footnotetext{
2 Pola Komunikasi Masyarakat Suku Nuhatan Sebagai Dampak Akulturasi Budaya (Aulia Vera Rosida, Juli Desember 2011), Pendidikan Nilai Sosial Budaya Dalam Keluarga Dan Lingkungan Masyarakat Suku Nuaulu Di Pulau Seram (Case Study: Di Desa Tamilou Kecamatan Amahai Kabupaten Maluku Tengah, (Jenny Koce Mattitaputy, April 2016), Sistem Religi Suku Nuaulu Di Pulau Seram Maluku Tengah (Fahham, 2016), The cultural relations of classification: an analysis of Nuaulu animal categoris from central Seram, Ellen Roy. (1993).

${ }^{3}$ Yonna Euinike Tanahitumesseng, Retty Ratnawati, Mufidah Cholil. (2017). Makna Menstruasi Bagi Perempuan Suku Naulu-Dusun Rohua Kabupaten Maluku Tengah Provinsi Maluku, Program Studi Kajian Wanita Universitas Brawijaya, IJWS - Vol. 5, No.1, 2017.
}

20 | P a g e

https://doi.org/10.25077/jantro.v22.n1.p19-28.2020

\section{B. METODE PENELITIAN}

$\mathrm{P}$ enelitian ini dilakukan dengan menggunakan metode kualitatif, karena dengan metode ini mampu menjawab tujuan penelitian. Penelitian dilakukan di Pulau Seram, khusus pada masyarakat Nuaulu di Dusun Yahalatan. Data dikumpulkan dengan metode, yakni Pertama adalah observasi kualitatif (qualitative obeservation) ${ }^{4}$, dimana penulis turun ke lokasi penelitian dan yang diamati adalah kegiatan ritual Pinamou. Kedua adalah wawancara kualitatif (qualitative interview) ${ }^{5}$, peneliti dapat melakukan face-to-face interview (wawancara berhadap-hadapan) dengan partisi-pan, mewawancarai mereka dengan telepon atau terlibat dalam focus group interview (wawancara dalam kelompok tertentu) yang terdiri dari enam sampai delapan partisipan per kelompok. Pertanyaan yang dikemukakan bersifat umum dan terbuka. Informan yang akan diwawancarai adalah kepala Suku Nuaulu, Kapitan Suku Nuaulu, beberapa perempuan yang telah melakukan ritual Pinamou, Mama bian yang merupakan pemimpin dalam melakukan ritual Pinamou, serta masyarakat setempat yang ada pada dusun Yahalatan. Ketiga adalah materi audio dan visual kualitatif (qualitative audio and visual materials) ${ }^{6}$. Data ini bisa berupa foto, objek seni, videotape, atau segala jenis suara/bunyi. Keempat adalah studi pustaka. Penulis memakai studi pustaka untuk memperoleh landasan teori melalui buku, literatur atau catatan-catatan terkait dengan penelitian yang dilakukan. Setelah melakukan penelitian, penulis akan menganalisis data yang diperoleh dari hasil wawancara dan juga observasi lapangan dan juga teknik lain yang dipakai secara sistematis agar pembaca dapat mudah untuk memahaminya.

\section{HASIL DAN PEMBAHASAN}

\section{Ritual Inisiasi menurut Arnold van Gennep}

$\mathrm{D}$ alam pengamatan seorang Van Gennep, bahwa ritual yang dilakukan bagi perempuan bukanlah ritual yang menciptakan struktur karena adanya pemisahan. Tetapi ritual ini menjadi sebuah transisi peran penting umumnya terdiri dari tiga fase: Pemisahan, di mana seseorang tidak terlibat dari peran atau status sosial; Transisi, di mana seseorang beradaptasi dan perubahan agar sesuai dengan peran baru; dan Penggabungan, dimana orang tersebut mengintegrasikan peran baru atau status ke dalam diri.

\footnotetext{
${ }^{4}$ John W. Creswell. (2016) Research Design, Pendekatan Metode Kualitatif, Kuantitatif, dan Campuran, Edisi ke 4, Yogyakarta: Pustaka Pelajar, 254.

${ }^{5}$ Creswell, Research Design, 254.

${ }^{6}$ Creswell, Research Design, 255.
} 
Pada tahap pemisahan, individu dipisahkan dari satu tempat atau kelompok atau status; dalam tahap peralihan, disucikan dan menjadi subjek dari prosedur-prosedur perubahan; sedangkan pada masa penggabungannya secara resmi ditempatkan ke pada suatu tempat, kelompok atau status baru.

Setiap tahapan yang disebut sebagai masa transisi itu berbeda-beda. Pada setiap individu terdapat fase yang berbeda, namun setiap fase ini tidak menjamin akan berlangsungnya tatanan sosial dalam suatu komunitas masyarakat. Setiap individu dalam suatu komunitas masyarakat tidak dapat langsung di identikan dengan maksud dalam setiap tahap kehidupan yang mengharuskan akan setiap tatanan dalam kehidupan masyarakat. Setiap tatanan kehidupan itu menjadi suatu pelajaran dan tolak ukur yang dijadikan sebagai ritual dan menjadi penanda akan suatu keberadaan seorang individu untuk ada dalam suatu komunitas. Setiap ritual dalam tahapan bahkan pemberlakuannya terhadap setiap individu dalam masyarakat tidak perlu untuk dipahami sebagai suatu pemisahan pada fase fisik misalnya lakilaki dan perempuan, yang mana sering kali dianggap terdapat ketimpangan dalam setia tahapan ritual yang dijalani oleh seorang perempuan. Ketimpangan ini menjadi bentuk budaya dalam konstruksi yang telah dibangun dalam masyarakat dalam kebudayaan patriaki. Perlu ditegaskan lagi bahwa penyelenggaraan ritual bukan hanya dalam masa batasan secara fisik saja tetapi bagaimana dapat membangun kehidupan komunitas dalam lingkup pribadi bahkan kelompok dalam masyarakat. Dalam tindakan dalam suatu ritual, pemutusan dalam hubungan secara sementara dengan masyarakat itu sebagai suatu tujuan untuk memisahkan fase yang dianggap lampau untuk dapat melihat fase baru dalam pandangan ke masa depan. Setiap tindakan yang dilakukan menjadi suatu tanda akan setiap tindakan yang ada dalam masyarakat. Namun tindakan itu tidak dipahami dalam pandangan yang hanya menyudutkan satu pihak tetapi menjadi bagian dalam pandangan secara bersama dalam suatu masyarakat. Ritus yang berkaitan dengan pemisahan menjadi suatu tujuan penggabungan dalam suatu komunitas masyarakat.

Pemisahan yang dilakukan dalam pandangan masyarakat suku bahkan masyarakat lain seperti kelas dan juga kasta sebenarnya merupakan suatu tatanan sosial yang secara bersama dirumuskan dan ditata, namun jika dilihat dalam pengaruh akan ritual yang dijalankan, maka ritual yang dijalankan bukan hanya sekadar pembatasan tetapi ada suatu penggabungan dan pembentuk nilai yang terkandung dalam ritual yang dijalankan dalam suatu komunitas masyarakat. Ritual merupakan suatu tahapan yang sakral yang dianggap sebagai upacara religious yang mengandung unsur penyembahan dan kepercayaan dalam tatanan komunitas masyarakat yang ada. Ritual yang dilakukan sebagai bentuk awal kehidupan. Meskipun terdapat tahapan dalam ritual namun setiap tahapan itu merupakan awal dalam penggabungan suatu individu yang menjalankan ritual dalam suatu komunitas masyarakat yang ada.

Ritual inisiasi menjadi tahapan ritual yang berhubungan juga dalam kepercayaan yang dilakukan secara sakral dalam masyarakat. Ritual inisiasi yang dilakukan sebagai bentuk penyucian diri, dan konsep tentang penyucian diri ini menjadi suatu pandangan yang bukan hanya pada agama terkemuka tetapi agama suku juga mengenal akan penyucian diri dalam setiap ritual yang dibangun dalam tatanan suatu komunitas masyarakat. Penyucian diri ini mejadi suatu fase baru dalam hal kelahiran kembali dalam tergabungnya suatu individu yang melakukan ritual dengan komunitas dalam suatu masyarakat.

Dalam pandangan Van Gennep tentang tahapan ritual inisiasi yang mengandung unsur didalamnya yakni pemisahan, transisi dan penggabungan, di tegaskan kembali Merry Douglas $^{7}$. Dalam kajiannya tentang Kemurnian dan bahaya, suatu analisis terhadap yang kotor dan tabu, Mary Douglas terfokus pada masyarakat primitive dan agama mereka yang dipandang sebagai masyarakat yang masih melekat dalam konsep pemahaman tentang yang kotor dan tabu. Masyarakat primitive dalam pengalaman budaya dapat diartikan sebagai nilai sosial yang menyimpang. Namun kita tidak bisa mengatakan bahwa ada ketimpangan dalam ritual mereka jika kita tidak melihat hal tersebut menjadi suatu bagian yang secara turun temurun telah ada dalam masyarakat tersebut. Contoh yang kotor misalkan bagi masyarakat primitive yakni menstruasi. Menstruasi dianggap sebagai hal yang kotor. Namun hal yang dianggap kotor ini dapat menjadi suatu kekuatan yang bisa saja menjadi baik dalam komunitas tetapi juga menjadi bahaya dalam komunitas itu sendiri. Setiap ritual yang berhubungan dengan pembersihan diri mempunyai kekuatan secara mistis. Kekuatan secara mistis ini ditonjolkan dan dapat dilihat ketika ritual ini tidak dilakukan. Ritual yang tidak dilakukan bagi hal yang dianggap kotor dalam suatu komunitas dapat menjadi ancaman bagi komunitas itu sendiri.

Ritual antara yang bersih dan yang kotor akan menciptakan suatu pengalaman yang baru, bahwa yang kotor dan yang bersih itu tidak perlu dilakukan pemisahan. Pemisahan yang ada dapat menimbulkan penghargaan yang minim

\footnotetext{
${ }^{7}$ Mary Douglas. (1966) Purity and Danger, An Analysis of the Concepts of Pollution and Taboo, New York: Routledge, 1966.
} 
bagi setiap leluhur kita sendiri. Sehingga setiap ritual yang dilakukan terkhusus bagi perempuan seperti halnya menstruasi, jangan dianggap sebagai suatu pemisahan. Menstruasi yang dialami oleh perempuan dianggap sebagai hal yang kotor mempunyai kekuatan dalam suatu komunitas. Sehingga yang kotor dapat menjadi yang suci dengan melihat aspek dari kekuatan yang ada. Menstruasi yang dialami oleh perempuan merupakan sebuah kemurnian. Sehingga ritual dilakukan sebagai bentuk perlindungan bagi perempuan yang memiliki kemurnian tersebut. Perlindungan ini pintu gerbang untuk menemukan anggota komunitas baru dalam kehidupan masyarakat. Melalui perempuan maka keanggotaan kasta ditentukan, melalui perempuan kemurnian dari anggota masyarakat terus diabadikan. Hal ini menegaskan pandangan pembatasan terhadap perempuan harus diakhiri. Perempuan memiliki kekuatan dalam komunitas masyarakat. Representasi perempuan sebagai kekuatan tidak hanya dilihat dalam kajian sebagai perempuan sebagai ibu saja. Perempuan sebagai ibu yang dapat melahirkan dan menjadi penyambung kehidupan dalam suatu komunitas. Sehingga pengasingan dalam ritual bagi perempuan bukanlah suatu pemisahan, tetapi merupakan suatu pengalaman yang dijadikan sebagai suatu kekuatan dalam komunitas masyarakat yang ada.

Teori diatas dapat mengarahkan kita tentang nilai penghargaan terhadap perempuan yang bukan hanya sebagai sebuah nilai tetapi juga memiliki pengaruh dalam suatu komunitas masyarakat. Ritual yang dilakukan untuk dapat menyeimbangkan kehidupan dalam masyarakat yang memegang nilai dan kepercayaan yang dibawa turun-temurun dari sejak para leluhur mereka ada. Setiap kepercayaan ini dibangun dalam mitologi yang menjadi sebuah penegasan terhadap tatanan nilai dalam masyarakat. Sehingga setiap tahapan ritual bukan hanya sebagai sebuah tradisi yang dibangun dan dilakukan dalam setiap pemaknaanya, tetapi mengandung unsur dalam kepercayaan yang dibangun dalam mitologi yang ada pada suatu komunitas.

\section{Penghargaan Perempuan dalam Mitologi orang Seram}

Pulau Seram yang ada dalam teritori wilayah daerah Maluku, memiliki pergeseran dalam pandangan kedudukan. Pergeseran ini ditunjukkan dengan perkembangan budaya patriakhi yang merebak secara luas dan menggusur pemahaman awal orang maluku yang berkaitan erat dengan matriakhi yang mempunyai pengaruh dan peran yang sangat besar dalam terbentuknya sejarah dan sepak terjang setiap komunitas dalam masyarakat maluku. Pengaruh masuknya budaya patriakhi ini di dalam perkembangan sejarah bangsa Eropa, yakni Portugis dan Belanda ${ }^{8}$. Matriakhi sendiri merupakan konstruksi sosial awal dari orang Maluku. Mitologi Nusa Ina yang menempatkan seorang Ina (perempuan) dalam sentral penciptaan. Perempuan sebagai peretas kehidupan mula-mula dalam sebuah teritori yang besar dengan situasi kehidupan beserta tatanan nilainya ${ }^{9}$.

Manusia awal (Alifuru) yang diciptakan pertama adalah perempuan atau lbu yang bernama Hulamasa ${ }^{10}$. Penciptaan Nusa Ina atau Pulau Seram bersamaan dengan penciptaan Ibu bumi yang melahirkan Alifuru Ina. Alifuru ${ }^{11}$ perempuan (Ina) atau seorang lbu adalah ciptaan awal Mahakuasa Pencipta Alam Semesta dan Manusia ${ }^{12}$. Nusa Ina merupakan sebuah nama yang mana manusia pertama kali yang diciptakan adalah seorang ina (perempuan) ${ }^{13}$. Mitologi Nusa Ina menggambarkan lakilaki (Alifuru Ama) sebagai pendatang dari "langit" memiliki jiwa petualang yang kemudian jatuh cinta pada sang pemilik bumi (Alifuru Ina). Alifuru Ama tidak dilihat sebagai ciptaan kemudian yang lebih rendah dari Alifuru Ina. Kosmologi Maluku yang menggambarkan laki-laki sebagai langit dan perempuan sebagai bumi. Perkawinan keduanya menjadi cikal-bakal kelahiran komunitas Maluku ${ }^{14}$. Mitos menceritakan tentang bagaimana melalui tindakan Supernatural Beings sebagai suatu realitas asali masuk ke dalam eksistensi kosmos, atau hanya sebagai bagian dari realitas seperti pulau, tanaman, kekhususan tingkah laku atau kebiasaan manusia, suatu lembaga, karenanya mitos selalu dikaitkan dengan penciptaan dan bagaimana segala sesuatu dijadikan $^{15}$.

Pulau Seram sebagai pulau ibu atau Nusa Ina sebagai tempat asal mula manusia Maluku yang pertama, tempat para tete nene moyang ${ }^{16}$ (leluhur) hidup dan membentuk tatanan dunia Seram dengan berbagai aturan adat yang dipegang hingga kini. Pulau Seram sebagai Nusa Ina (Pulau Ibu), karena perempuan atau Ina yang diciptakan pertama kali mengandung makan bagi orang Maluku bahwa perempuan atau Ina dan dunia berada dalam konsep penciptaan awal dan setara. Figur Ina karena ia yang mengandung, melahirkan, memberi makan dan membesarkan semua anak. Narasi mitologi penciptaan bumi

\footnotetext{
${ }^{8}$ Wedelmina Yudit Tiwery. (2015) Teologi Ina, Terlahir dari Rahim Maluku, Jakarta: Bpk Gunung Mulia, 117.

${ }^{9}$ Tiwery, Teologi Ina, Terlahir dari Rahim Maluku, 118.

${ }^{10}$ Tiwery, Teologi Ina, Terlahir dari Rahim Maluku, 135.

${ }^{11}$ Suku awal orang Maluku.

12 Tiwery, Teologi Ina, Terlahir dari Rahim Maluku, 135-136.

${ }^{13}$ Tiwery, Teologi Ina, Terlahir dari Rahim Maluku, 139.

${ }^{14}$ Tiwery, Teologi Ina, Terlahir dari Rahim Maluku, 143-145.

${ }^{15}$ Tiwery, Teologi Ina, Terlahir dari Rahim Maluku, 153.

${ }^{16}$ Sebutan untuk leluhur orang Maluku.
} 
Nusa Ina dengan Nunusaku telah melahirkan kesadaran yang kuat dalam diri masyarakat tentang peran seorang Ina. la adalah gambaran sebuah tatanan kehidupan mula-mula di bumi Nusa Ina yang ramah, suka menolong orang lain dalam susah. Seorang Ina yang menjadi peletak awal kehidupan komunalitas di Nunusaku ${ }^{17}$. Mitos tersebut mengedepankan tema persaudaraan di antara sesama manusia dengan menjadikan Nunusaku sebagai pusat bersama dan Alifuru Ina sebagai Ibu bersama. Nilai persaudaraan dan keibuan adalah nilai yang sangat relevan untuk digemakan dan digumuli dalam konteks kehidupan masyarakat di Maluku saat ini dan bahkan seterusnya ${ }^{18}$.

Penghargaan terhadap perempuan dibentuk dalam mitologi yang ada dalam kehidupan masyarakat. Mitos yang dalam perkembangan zaman menjadi runtuh karena pengaruh budaya luar yang masuk dalam masyarakat. Ritual merupakan sebuah jalan masuk untuk mengingat kembali mitologi kehidupan dalam suatu masyarakat sebagai cerminan kehidupan yang dipegang sejak awal dalam masyarakat. Mitos dipahami bukan sekadar seni verbal/ cerita masyarakat setempat, melainkan merupakan upaya untuk mengungkapkan atau merefleksikan realitas keberadaan masyarakat pemiliknya ${ }^{19}$. Menurut Eliade, mitos adalah sejarah mengenai apa yang terjadi di masa lalu. Pemikiran Eliade terhadap mitos merupakan cara masyarakat arkhais menceritakan keberadaan mereka melintasi dunia yang supranatural menuju kenyataan dunia ini dan cerita ini dianggap kudus sehingga perlu adanya pewarisan bagi generasi berikutnya. Bahwa untuk mengetahui keberadaan/asal usul maupun segala ritus dan tindakan mereka di dunia dapat dipahami melalui kenyataan-kenyataan yang ditunjukkan oleh mitos tersebut ${ }^{20}$. Masyarakat arkhais adalah masyarakat yang hidup di zaman pra sejarah ataupun masyarakat tribal dengan kebudayaan terbelakang yang hidup saat ini. Sehari-hari mereka mengerjakan pekerjaan "alami", seperti berburu, memancing dan bercocok tanam ${ }^{21}$.

Mitos-mitos sendiri merupakan simbol-simbol berwujud narasi ${ }^{22}$. Mitos-mitos menceritakan tentang Yang Sakral, bagaimana kehidupan ilahiah yang bersifat supranatural itu bisa menjadi sangat dekat dengan kehidupan alamiah manusia. Simbol-simbol tersebut bukan hanya mengemukakan kepada kita tentang dunia Yang Sakral, tapi juga kontinuitas antara struktur eksistensi manusia dengan struktur kosmik.

\footnotetext{
${ }^{17}$ Tiwery, Teologi Ina, Terlahir dari Rahim Maluku, 177.

${ }^{18}$ Tiwery, Teologi Ina, Terlahir dari Rahim Maluku, 123.

${ }^{19}$ Tiwery, Teologi Ina, Terlahir dari Rahim Maluku, 119.

${ }^{20}$ Tiwery, Teologi Ina, Terlahir dari Rahim Maluku, 169-170.

21 Daniel L. Pals. (2012) Seven Theories of Religion, Yogyakarta: IRCiSoD, 233.

${ }^{22}$ Pals, Seven Theories of Religion, 241.
}

Mitos-mitos tersebut tidak hanya merefleksikan daur kehidupan dan kematian di alam semesta, tapi juga merefleksikan bagaimana daur perjuangan hidup personal dalam setiap individu manusia; drama kelahiran, kehidupan, kematian serta harapan untuk dilahirkan kembali untuk penebusan dosa ${ }^{23}$. Penting bahwa aktivitas dalam ritual untuk bertemu dengan yang sakral.

Ritual inisiasi, pengampunan, dan penebusan dosa adalah ritual, yang dengan berbagai cara dan prosedur, menampilkan kembali proses penciptaan asali yaitu penciptaan dunia yang berawal dari chaos dan setelah itu wujud dunia diberikan antar dewa tersebut ${ }^{24}$. Tema-tema yang ada di dalam setiap ritual dan mitos-mitos arkhais adalah keinginan untuk hidup di satu dunia sebagaimana yang datang dari tangan sang pencipta, sebuah dunia yang murni dan maha kuat. Mitos tentang penciptaan berperang penting dalam masyarakat arkhais. Ritual dalam masyarakat arkhais mengandung "pengulangan" kembali apa yang Tuhan lakukan pada waktu illo tempore (berasal dari bahasa latin Latin yang berarti "pada waktu itu"), yaitu saat alam semesta mendapatkan wujudnya. Setiap festival Tahun Baru, mitos kelahiran kembali dan reintegrasi, atau ritual inisiasi adalah perlambang "kembali" ke awal, satu kesempatan untuk memulai dunia baru $^{25}$.

\section{PINAMOU: Ritual inisiasi bagi perempuan Nuaulu}

Ritual inisiasi merupakan ritual yang ada dalam setiap komunitas masyarakat. Ritual menjadi bagian dalam kehidupan suatu komunitas yang ada dalam masyarakat. Pinamou merupakan salah satu ritual inisiasi yang ada di Suku Nuaulu bagi seorang perempuan yang dilakukan dalam pengalihan status dari seorang wanita dari masa kanak-kanak ke masa dewasa. Secara harafiah Pinamou diartikan sebagai wanita bisu. Namun bisu bukan berarti tidak mengatakan sepatah katapun. Bisu dalam hal ini diartikan bahwa perempuan yang melakukan ritual Pinamou dapat bebicara namun tidak mengeluarkan suara dengan keras. Ritual Pinamou sendiri telah ada turun temurun dari sejak para leluhur. Ritual ini merupakan ritual yang wajib untuk dilakukan oleh setiap perempuan dalam masa akhil balik mereka. Hal ini ditandai dengan menstruasi yang didapat oleh seorang perempuan.

Ketika seorang perempuan mengalami menstruasi perempuan ini memberitahukannya pada Ibu dari perempuan tersebut. Ibu dari perempuan ini melarikan anak perempuan ini kedalam hutan sebelum dimasukan kedalam

\footnotetext{
${ }^{23}$ Pals, Seven Theories of Religion, 244-246.

${ }^{24}$ Pals, Seven Theories of Religion, 251.

${ }^{25}$ Pals, Seven Theories of Religion, 256-257.
} 
rumah kecil yang telah disediakan oleh masyarakat dan keluarga. Setelah itu lbu dari anak perempuan ini memberitahukan kepada keluarga bahwa ritual Pinamou harus dilakukan. Setelah ada kesepakatan dalam keluarga maka perempuan yang melaukan ritual Pinamou ditempatkan pada sebuah rumah kecil yang disebut Posune.

Didalam rumah Posune ini terdapat peralatan yang akan digunakan bagi perempuan yang melakukan ritual Pinamou. Peralatan yang digunakan oleh perempuan yang melakukan ritual Pinamou ini terdiri dari bambu. Peralatan masak bahkan mandi dari perempuan yang melakukan ritual Pinamou ini bersifat alami. Tidak berhubungan dengan peralatan modern. Makanan yang akan dimakan oleh perempuan yang melakukan ritual Pinamou ini juga bersifat alami seperti ubu-ubian dan juga makanan yang hanya direbus. Di dalam Posune, perempuan yang melakukan ritual Pinamou ini didampingi oleh 2 orang Mama bian. Mama bian mempunyai tugas dan fungsi untuk menasihati perempuan yang melakukan ritual Pinamou ini dan juga menjadi media interaksi bagi perempuan Pinamou untuk mengikuti jalannya ritual Pinamou ini. Mama bian berperan aktif dalam melihat, memperhatikan dan mengatur jalannya ritual Pinamou ini.

Setelah berada dalam posune selama menstruasi, Pinamou akan dikeluarkan dari dalam posune dengan tahapan yang ada dalam ritual yang dijalankan. Hal yang pertama dilakukan adalah meratakan gigi atau dalam dialek setempat disebut dengan Papar gigi. Papar gigi dilakukan dengan 3 buah batu khusus. Papar gigi ini dilakukan dengan tujuan untuk meratakan gigi dari perempuan yang melakukan Pinamou. Bagi masyarakat Suku Nuaulu, Perempuan yang memiliki gigi yang rata dan rapih terlihat menarik. Tahapan selanjutnya adalah Pinamou dimandikan. Perempuan yang melakukan ritual Pinamou dimandikan oleh mama-mama (ibu-ibu) yang ada dalam komunitas suku nuaulu. Perempuan yang melakukan ritual Pinamou dimandikan dengan kelapa, dan juga kunyit. Kelapa digunakan untuk membersihkan kotoran pada tubuh perempuan yang melakukan ritual Pinamou ini. Sementara kunyit dipakai untuk mencerahkan warna kulit dari perempuan yang melakukan ritual Pinamou ini.

Setelah dimandikan kemudian perempuan yang melakukan ritual Pinamou diberikan kain baru. Kain baru ini menggantikan kain yang lama yang dipakai selama perempuan yang melakukan Pinamou ini berada dalam Posune. Kain baru ini sebagai simbol pembersihan diri dari seorang perempuan. Setelah itu perempuan yang melakukan ritual Pinamou ini dibawa keluar dari Posune dan kemudian berjalan bersama ibu- ibu untuk menuju rumah besar dari perempuan yang melakukan ritual Pinamou ini. Setelah sampai rumah besar, Mama bian mendadani perempuan yang melakukan Pinamou ini dengan aksesoris yang dikenakan. Setelah didandani, perempuan yang melakukan ritual Pinamou ini diberi makan. Makanan yang diberikan pada perempuan yang melakukan ritual Pinamou ini masih bersifat ubi-ubian. Makanan yang diberikan oleh Mama bian kepada perempuan yang melakukan ritual Pinamou ini tidak ditelan tetapi dibuang kembali sesuai instruksi dari Mama biang. Hal ini dilakukan sebagai tanda penghargaan terhadap hasil pencarian dari keluarga bagi perempuan yang melakukan ritual Pinamou. Setelah acara makan, perempuan yang melakukan ritual Pinamou, berjalan mengelilingi kampung untuk membagikan minyak khusus bagi setiap masyarakat. Minyak khusus ini diperuntukan bagi masyarakat laki-laki baik yang kecil maupun dewasa. Hal ini dilakukan Karena pemahaman masyarakat suku nuaulu sendiri bahwa perempuan merupakan sumber berkat. Jadi minyak yang diberikan dapat menjadi sebuah doa bagi laki-laki yang ada dalam masyarakat suku nualu dalam tugas untuk mencari nafkah bagi keluarga.

\section{PINAMOU: Penghargaan terhadap Perempuan Nuaulu dalam Ritual Inisiasi di Pulau Seram}

Dalam tahapan ritual yang ada maka penghargaan bagi perempuan di lihat dalam ritual khusus bagi perempuan. Bagi Van Gennep, kekhususan itu tidak bisa dilepaspisahkan. Ritual Pinamou dilakukan dalam tahapan yang ada merupakan sebuah pengkhususan yang dilakukan bagi seorang perempuan. Dalam kacamata patriakal ritual ini dapat menjadi suatu legitimasi oleh kaum laki-laki atas perempuan. Namun dapat dilihat bahwa akhir dari ritual Pinamou ini adalah pemberian minyak bagi setiap laki-laki yang ada dalam masyarakat suku nuaulu sebagai bentuk kepercayaan bagi perempuan sebagai saluran berkat bahkan saluran kehidupan dalam masyarakat. Ritual Pinamou yang ditandai dengan menstruasi yang dianggap kotor itu menjadi suatu kekuatan dalam masyarakat. Terdapat proses pembelajaran yang dapat dilihat adalah bahwa pengkhususan dalam ritual Pinamou bagi perempuan Naulu ini menunjukan bahwa perempuan yang menjalani ritual Pinamou ini mendasari akan pengkhususannya untuk menjadi seorang lbu, sebagai penerus kehidupan.

Proses pembelajaran yang kedua dalam budaya Pinamou dapat terlihat dari peranan Mama bian yang dijadikan sebagai agen budaya. Mama bian dalam ritual Pinamou ini sebagai sosok yang akan mengajarkan perempuan yang 
melakukan ritual Pinamou tentang kehidupan yang akan dijalani setelah nantinya ia berada dalam masyarakat dan menjadi seorang perempuan yang dewasa. Mama bian merupakan agen yang menjadi passing down, teaching yang mana peran Mama bian menurunkan ajaran secara komunal terhadap perempuan yang melakukan ritual Pinamou itu sendiri yang nanti diteruskan oleh perempuan tersebut dalam kehidupan sehari-harinya, bagaimana menjadi perempuan yang baik dan sebagainya. Dapat juga dikatakan dalam ritual Pinamou, perempuan dikhususkan didalam rumah Posune maka perempuan tersebut sementara mengalami katekisasi cultural yang dijalankan oleh perempuan. Dimana dalam pembelajaran ini dapat memberikan pandangan tentang bagaimana perempuan dalam kehidupan bermasyarakat yang melakukan ritual dalam kepercayaan sebagai pemeluk agama suku yakni Suku Nuaulu.

Dengan ritual Pinamou yang dilakukan maka Pinamou menjadi sebuah wadah untuk menempatkan Perempuan Nuaulu pada pusat kehidupan. Perempuan dalam ide dan gagasan yang berkembang dalam masyarakat dianggap sebagai sosok yang lemah. Dalam beberapa faktor ide dan gagasan ini mengalami perkembangan dalam masyarakat. Pandangan perempuan sebagai yang lemah dipahami dalam nilai alamiah yang ada dalam diri perempuan. Teori Nature (Kodrat alam) beranggapan bahwa perbedaan psikologisa antara laki-laki dan perempuan disebabkan oleh faktor-faktor biologis dari kedua insan tersebut ${ }^{26}$. Teori ini kemudian didorong dalam pandangan pembedaan antara laki-laki dan perempuan. Pembedaan dalam ide tentang perempuan secara kodrat dianggap lebih lemah dari laki-laki telah mengalami perkembangan bukan saja pada masyarakat awam tetapi juga dalam kalangan filsafat yang terus menerus mengalami perkembangan dalam pemikiran tentang kaum perempuan.

Perempuan dalam perannya pada kehidupan masyarakat dihubungkan dalam setiap nilai budaya dan gagasan yang berkembang dalam masyarakat itu sendiri. Berbagai pandangan tentang peran bagi seorang perempuan seringkali terbentuk dalam setiap gagasan tentang bagaimana perempuan berperilaku dan kemudian gagasan itu diturunkan secara turuntemurun $^{27}$. Gagasan ini juga berkaitan dengan segala kebiasaan yang ada dalam setiap kelompok bahkan setiap kesukuan. Bagi mereka yang menjalankan dan memiliki gagasan ini melihatnya dari sudut pandang mereka sendiri

\footnotetext{
${ }^{26}$ Kasiyan. (2008). Manipulasi dan Dehumanisasi Perempuan dalam iklan, Yogyakarta: Ombak, 33.

${ }_{27}$ Brunetta R. Wolfman. (1989). Peran Kaum Wanita, Bagaimana menjadi cakap dan seimbang dalam aneka peran, Yogyakarta: Kanisius, 12.
}

dan menganggap itu benar. Hal itu yang dalam gagasan mereka dianggap sebagai sebuah keteraturan dalam masyarakat mereka sendiri. Namun yang diperhadapkan adalah persoalan dengan yang lain yang melihat akan adanya ketimpangan akan gagasan yang dipikirkan yang dilaksanakan dalam suatu ritual. Hal yang perlu untuk ditekankan adalah tidak semua hal dapat dianggap sebagai hal yang menyimpang karena bagi mereka yang memiliki gagasan itu segalanya yang dipikirkan mempunyai nilai dalam sistem kelompok sosial yang mereka sendiri miliki. Stigma terhadap peran perempuan juga di budayakan dalam kebudayaan popular yang ditampilkan dan dalam pesan tradisionalnya adalah bahwa seorang perempuan itu lemah dan membutuhkan perlindungan dari laki-laki ${ }^{28}$. Kebudayaan popular yang ditampilkan seperti film, musik dan bacaan-bacaan yang ada dan berkembang dalam masyarakat. Kebudayaan popular mendorong akan pandangan terhadap seorang perempuan dalam masyarakat dan menjadi suatu tanda bagi perempuan sebagai sosok yang lemah. Perempuan dalam pandangan dari segi kebudayaan menjadi sosok yang lemah. Namun setiap yang alami dari kehidupan perempuan tidak dianggap sebagai sesuatu yang berharga tetapi dianggap dalam sistem nilai budaya yang dalam anggapannya menitikberatkan pada titik lemahnya seorang perempuan.

Hal yang bersifat alami dalam kodrat bagi seorang perempuan sering kali dianggap sebagai hal yang dianggap tabu atau kotor. Namun dari setiap ide dan gagasan yang ada perlu untuk dilihat adalah sebuah kekuatan dari hal yang secara kodrat yang menstigmakan perempuan sebagai sosok yang lemah. Menstruasi yang dialami oleh perempuan, dianggap sebagai suatu hal yang kotor. Mestruasi dianggap sebagai suatu yang kotor bagi masyarakat Nuaulu sebagai penghalang terhadap roh leluhur, sehingga perempuan yang melakukan ritual ini mempunyai tempat khusus yakni didalam rumah Posune. Rumah Posune menjadi tempat bagi seorang perempuan Nuaulu dalam menjalankan tradisi Pinamou ini. Pertanyaan menarik adalah jika menstruasi bagi perempuan Nuaulu sendiri dianggap kotor mengapa harus ada rumah yang dipersiapkan bagi perempuan Nuaulu yang mendapat menstruasi dan akan menjalankan tradisi Pinamou? hal ini dapat saja mendapat pengertian bahwa perempuan selalu mempunyai tempat yang penting dalam kehidupan masyarakat. Sehingga perempuan yang mengalami menstruasi dan menjalakan tradisi Pinamou mempunyai rumah khusus yang akan ditinggali selama menjalani masa menstruasi dan juga dalam menjalankan ritual Pinamou tersebut.

\footnotetext{
${ }^{28}$ Wolfman, Peran Kaum Wanita, Bagaimana menjadi cakap dan seimbang dalam aneka peran, 15.
} 
Pemisahan yang dilakukan bukan untuk menciptakan struktur dalam masyarakat. Struktur yang mengklaim akan peran laki-laki yang dominan dalam masyarakat. Ritual Pinamou ini menunjukan bahwa perempuan mendapat tempat tertinggi, dihargai kerena perempuan menjadi pusat kehidupan bagi suatu masyarakat dan juga menjadi penyambung kehidupan dalam suatu masyarakat. Perempuan mempunyai penghargaan dan perlu untuk dihargai dalam sebuah komunitas. Perempuan memperoleh kekhususan dalam melanjutkan kehidupan dalam suatu komunitas. Perempuan sedang mengambil peran penting dalam masyarakat meskipun terlihat dalam setiap ritual perempuan itu sering tidak mendapat tempat atau terpinggirkan. Seperti yang diungkapkan oleh Martines bahwa perempuan dalam ritual sering kali terpinggirkan karena dipengaruhi pemahaman patriaki yang sangat tinggi kemudian ruang bagi perempuan itu tidak diberikan ${ }^{29}$. Dalam hal ini perlu untuk dilihat adalah bahwa sebenarnya perempuan memainkan peran yang sangat besar baik itu di dalam setiap ritual tetapi juga sebagai penerus kehidupan. Perempuan sangat dibutuhkan hampir disetiap aspek kehidupan yaitu di dalam keluarga menjadi ibu dan istri sedangkan di luar lingkungan itu perempuan juga bekerja ${ }^{30}$. Ritual inisiasi dalam tahapan yang dilakukan pemisahan dan kemudian penggabungan kembali menjadi sebuah ritual yang menonjolkan akan pengahargaan terhadap perempuan dalam ritual yang di padukan dengan kepercayaan sebagai agama suku. Perempuan memiliki tempat khusus dan dihargai dengan pemberlakukan dalam ritual inisiasi yang dilakukan seperti ritual Pinamou. Ritual yang dijalankan mempunya makna yang mendalam yang menegaskan akan penghargaan terhdap seorang perempuan yang ada dalam masyarakat bahkan komunitas setempat sebagai penerus kehidupan dalam suatu masyarakat bahkan komunitas yang ada. Ritual dijalakan dalam kepercayaan dan ketaatan yang diyakini sebagai yang sakral dan menjadi wadah yang meperlihatkan bahwa perempuan mempunyai peran yang besar dalam masyarakat ditengah stigma dan pandangan tentang perempuan yang melihat struktural dalam masyarakat dan mengabaikan makna sakral yang mengandung unsur penghargaan terhadap seorang perempuan sebagai penerus kehidupan.

\footnotetext{
${ }^{29}$ Jan van Bremen and D.P. Martinez. (1995), Ceremony and Ritual ini Japan, Ritual Practics in an industrialized society, New York: Routledge.

${ }^{30}$ SOLUSI KONFLIK PERAN PEREMPUAN MINANGKABAU (Kasus Perawat Yang Melanjutkan Pendidikan Ke Perguruan Tinggi) Nola Mutiara Asril, Maihasni, Alfitri (Department of Sociology, Faculty of Social and Political Science, Universitas Andalas, Padang, Indonesia), Jurnal Antropologi:Isu-Isu Sosial Budaya- Vol.21 no.02 (December 2019), 198
}

26 | P a g e

https://doi.org/10.25077/jantro.v22.n1.p19-28.2020

\section{KESIMPULAN}

$\mathrm{R}$ itual inisiasi dapat dikatakan merupakan pintu masuk dalam setiap tahapan kehidupan manusia yang ada dalam suatu komunitas masyarakat. Ritual inisiasi membantu untuk memperkenalkan nilai yang ada dalam suatu komunitas masyarakat, tetapi juga menjadi sebuah pemahaman baru bagi setiap kedudukan dalam anggota masyarakat. Ritual Pinamou menjadi sebuah cerminan akan sebuah penghargaan bagi perempuan nuaulu dan dapat dipakai sebagai sebuah cerminan bagi setiap perempuan dalam mempertahankan dan menjaga kontribusi dalam kehidupan bermasyarakat. Ritual Pinamou, telah menjadi bagian dari komunitas, dan didalam ritual ini relasi-relasi dalam kehidupan bermasyarakat dapat terbentuk satu dengan yang lain. Ritual Pinamou ini menjadi bagian penting dalam komunitas karena perempuan yang mengalami pengkhususan itu mempunyai peran yang sangat penting terhadap suatu komunitas karena perempuan tersebut yang akan memberi kehidupan dalam komunitas tersebut dengan memberi dan mendidik anak dalam komunitas yang ada yakni komunitas dalam suku nuaulu.

Dalam sisi yang lain orang bisa saja melihat ritual ini apalagi pengkhususan yang lebih dikaitkan dengan pengasingan dari perempuan dalam ritual ini dalam rumah kecil sebagai sebuah tindakan diskriminasi. Apalagi dalam isu yang berkembang sekarang untuk melihat sisi perempuan maka ritual ini juga dapat merujuk pada bagian diskriminasi. Tetapi dalam penulisan ini menekankan bagaimana melihat relasi perempuan sebagai ibu, yang didorong dalam penghargaan akan alam sebagai ibu dan melihat kesucian komunitas yang ada. Maka dapat terlihat dengan jelas bahwa ritual Pinamou ini merupakan juga penghargaan terhadap perempuan. Dimana perempuan yang menjalankan budaya ini dikhususkan dan mendapatkan pembelajaran yang dapat dijadikan sebagai suatu hal yang akan menjadikan perempuan sebagai sosok yang penting dalam suatu komunitas sebagai penerus kehidupan dalam keluarga bahkan dalam komunitas itu sendiri. Sehingga pengkhususan perempuan sebagai suatu yang penghargaan sebagai perempuan sebagai penerus kehidupan.

Ritual Pinamou dapat menjadi suatu pengakuan iman dalam kepercayaan agama suku yang dapat dilihat dan data terus diperbaharui. Mitologi dalam kehidupan sebuah komunitas dapat dilihat dalam setiap ritual yang memiliki narasi dan makna yang terkandung dalam sejarah yang telah diwariskan dari generasi ke generasi. Pemahaman baru yang masuk dan melunturkan narasi tentang mitologi dapat ditantang dalam setiap ketahanan dalam 
pemberlakukan ritual yang disoroti dalam pandangan dan makna dalam sebuah komunitas, sehingga dengan berlangsungnya sebuah ritual maka setiap mitologi, nilai dan kepercayaan dapat tetap terjaga dalam suatu komunitas. Cara berpikir laki-laki yang sering membuat akan peran perempuan yang tertutup ditegaskan kembali dalam ritual Pinamou yang ingin melihat dan mendorong perempuan ke depan untuk melihat peran lain dari perempuan sebagai lbu, sakralitas dan juga kesucian komunitas. Pengaruh perempuan dalam relasi sosial dalam masyarakat menjadi nilai penting dalam sebuah komunitas karena peran dari perempuan sebagai ibu yang meneruskan narasi-narasi dalam ceritacerita bahkan nasihat bagi anak-anak. Perempuan sebagai ibu mempunyai peran penting untuk meneruskan pengetahuan komunitas bagi anak-anak yakni generasi yang ada. Yang bagian penting juga dalam nilai sosiologi agama adalah bagaimana dengan ritual ini orang dapat memperkuat relasi-relasi sosial antar masyarakat yang menjadikan perempuan sebagai sosok yang penting dalam ritual Pinamou itu sendiri yang menegaskan secara gamblang bahwa perempuan ini merupakan sosok yang menjadi penerus dalam kehidupan keluarga bahkan terlebih dalam komunitas yang ada yakni dalam komunitas masyarakat nuaulu.

Penulisan ini memberikan beberapa usulan yang dapat dipertimbangkan untuk melihat kebudayaan yang hampir terkikis dan mengalami pergeseran makna yang tidak secara natural tetapi dipandang berbeda dalam kemajuan pemikiran dan zaman, terlebih dalam konteks budaya lokal:

1. Budaya selalu melekat dan menjadi kebiasaan suatu masyarakat sehingga secara sengaja atau tidak akan selalu diterapkan dari generasi ke generasi. Oleh karena itu, setiap kelompok masyarakat akan memiliki budayanya masing-masing. Budaya ini akan terus diterapkan dan dipegang teguh oleh individu dari suatu kelompok masyarakat ${ }^{31}$. Teks budaya lokal dapat memberikan makna yang lebih berguna dalam kesejajaran sosial dalam masyarakat. Dalam pemikiran tentang perempuan dalam masyarakat yang dianggap rendah dalam hubungan patriakhi yang telah berkembang dalam masyarakat dan menjadikan perempuan menjadi sosok yang sering tidak dianggap ditepis dengan ritual yang diberlakukan dalam suatu komunitas yang mengandung penghargaan terhadap seorang perempuan yang menjadi penerus suatu kehidupan dalam masyarakat. $\mathrm{Hal}$ ini berhubungan dengan keberlanjutan kehidupan dalam setiap inidividu yang ada dengan keturunan dalam suatu komunitas dan juga sebagai pemberi berkat dalam kehidupan bagi laki-laki dan juga komunitas dalam masyarakat.

2. Teks budaya lokal menjadi bagian penting yang berisikan tentang narasi-narasi, kepercayaan dalam mitologi yang mengandung makna yang sangat mendalam bagi sebuah tatanan kehidupan dalam masyarakat. Dimana dalam kepercayaan yang dibangun dengan mitologi yang ada, menciptakan keselarasan dalam hubungan sesama dan masyarakat yang ada dalam suatu komunitas dan ruang lingkup sosial. Mitologi tentang perempuan mempengaruhi penghargaan terhadap perempuan, dengannya maka mitos bukan hanya sekedar cerita tetapi sebagai suatu narasi yang harus dibangun dalam konteks kebudayaan patriakhi yang sering berkuasa. Mitologi dari seorang perempuan dapat mengubah kembali pemikiran dalam masyarakat terhadap seorang perempuan.

\section{E. UCAPAN TERIMA KASIH}

U capan terimakasih penulis sampaikan kepada pihak-pihak yang telah membantu kelancaran dalam penelitian ini, baik itu sumbangan pemikiran dan materi. Terkhusus untuk masyarakat Dusun Yalahatan, Pulau Seram untuk setiap informasi yang diberikan, yang terus menjalankan ritual dalam setiap siklus kehidupan yang ada dalam komunitas sebagai agama Suku yang memiliki kepercayaan dan tetap menghargai warisan leluhur yang dijalakan dalam ritual yang memiliki makna yang dapat membuka pikiran yang baik dalam kehidupan sebagai masyarakat yang menjalankan ritual sebagai budaya dan kepercayaan yang dipegang sebagai sesuatu yang memiliki nilai yang sakral.

\footnotetext{
${ }^{31}$ Budaya Rimpu Sebagai Eksistensi Perempuan Islam Di Tanah Bima, Ayu Fitriana, Suharno, Department of Civic Education, Graduate School, Universitas Negeri Yogyakarta, Indonesia Jurnal Antropologi: Isu-Isu Sosial Budaya-Vol.21 no.02 (December 2019), 211
} 


\section{DAFTAR PUSTAKA}

Asril Nola Mutiara, Maihasni, Alfitri. (2019). 'Solusi Konflik Peran Perempuan Minangkabau (Kasus Perawat Yang Melanjutkan Pendidikan Ke Perguruan Tinggi'. Jurnal Antropologi: Isu-Isu Sosial Budaya-Vol.21 no.02, 198

Bremen van Jan and Martinez P. D. (1995). Ceremony and Ritual ini Japan, Ritual Practices in an industrialized society, New York: Routledge.

Creswell W John. (2016). Research Design, Pendekatan Metode Kualitatif, Kuantitatif, dan Campuran, Edisi ke 4, Yogyakarta: Pustaka Pelajar.

Douglas Mary. (1966). Purity and Danger, an Analysis of the Concepts of Pollution and Taboo, New York: Routledge.

Ellen Roy. (1993). The cultural relations of classification: an analysis of Nuaulu animal categoris from central Seram,

Fitriana Ayu, Suharno. (2019). 'Budaya Rimpu Sebagai Eksistensi Perempuan Islam Di Tanah Bima'. Jurnal Antropologi: Isu-Isu Sosial Budaya-Vol.21 no.02, 211.

Gennep van Arnold. (1960). The Rites of Passage, Translated by Monika B. Yizedom And Gabrielle L. Caffee, The University Of Chicago Press.

Kasiyan, (2008). Manipulasi dan Dehumanisasi Perempuan dalam iklan, Yogyakarta, Ombak.

Matitaputty Koce Jenny. (2016). 'Pendidikan Nilai Sosial Budaya Dalam Keluarga Dan Lingkungan Masyarakat Suku Nuaulu Di Pulau Seram (Case Study: Di Desa Tamilou Kecamatan Amahai Kabupaten Maluku Tengah)', Vol 4, No 1.I

Pals L Daniel. (2012). Seven Theories of Religion, Yogyakarta: IRCiSoD.

Rozida Vera Aulia. (2011). 'Pola Komunikasi Masyarakat Suku Nuhatan Sebagai Dampak Akulturasi Budaya, Vol 1, No 1.

Tanahitumesseng Euinike Yonna, Ratnawati Retty, Cholil Mufidah. (2017). 'Makna Menstruasi Bagi Perempuan Suku Naulu-Dusun Rohua Kabupaten Maluku Tengah Provinsi Maluku, Program Studi Kajian Wanita Universitas Brawijaya', IJWS - Vol. 5, No.1.

Tiwery Yudit Wedelmina. (2015). Teologi Ina, Terlahir dari Rahim Maluku, Jakarta: Bpk Gunung Mulia.

Wolfman R Brunetta. (1989). Peran Kaum Wanita, Bagaimana menjadi cakap dan seimbang dalam aneka peran, Yogyakarta: Kanisius. 